\title{
Pengaruh Sistem E-learning Adeles2tp Bermodelkan Blended Learning Terhadap Hasil Belajar Siswa (Studi Kasus: Kelas X Akuntansi pada Mata Pelajaran Simulasi dan Komunikasi Digital di SMK Negeri 1 Seririt)
}

\author{
Kadek Alan Budiana ${ }^{1}$, Ketut Agustini ${ }^{2}$, Gede Saindra Santyadiputra ${ }^{3}$ \\ Jurusan Pendidikan Teknik Informatika \\ Universitas Pendidikan Ganesha \\ Email : allan_budiana@yahoo.com ${ }^{1}$, ketutagustini@undiksha.ac.id ${ }^{2}$, gsaindras@undiksha.ac.id ${ }^{3}$
}

\begin{abstract}
Abstrak- Penelitian ini bertujuan untuk mengetahui (1) pengaruh sistem e-learning adeles $2 t p$ bermodelkan blended learning pada mata pelajaran Simulasi dan Komunikasi Digital terhadap hasil belajar siswa kelas X Akuntansi SMK Negeri 1 Seririt (2) Untuk mengetahui respon siswa terhadap penerapan system e-learning bermodelkan blended learing pada mata pelajaran Simulasi dan Komunikasi Digital. Sistem e-learning yang digunakan dalam penelitian ini adalah adeles2tp dengan konten SMK Negeri 1 Seririt. Jenis penelitian ini adalah eksperimen semu (quasi eksperimen) dengan desain Post Test Only Control Group Design. Populasi penelitian mencakup semua siswa kelas X Akuntansi SMK Negeri 1 Seririt Tahun Ajaran 2018/2019. Sampel yang digunakan yaitu kelas $\mathrm{X}$ AK 1 yang digunakan sebagai kelas eksperimen dan X AK 2 yang digunakan sebagai kelas kontrol, dengan jumlah 70 orang. Metode pengumpulan data yang digunakan yaitu dengan metode tes pilihan ganda untuk mengatur ranah kognitif kemudian dianalisis dengan meliputi uji normalitas, uji homogenitas, uji hipotesis dan metode kuisioner untuk melihat respon siswa.Manfaat hasil penelitian ini dapat meningkatkan hasil belajar pengetahuan siswa terhadap mata pelajaran Simulasi dan Komunikasi Digital serta respon siswa terhadap media pembelajaran e-learning .
\end{abstract}

Kata Kunci: e-learning, blended learning, adeles2tp, Post Test Only Control Group Design.
Abstract- The purposes of this study were (1) the effect of the adeles2tp e-learning system modeled on blended learning in Digital Simulation and Communication subjects on the learning outcomes of class X Accounting of SMK Negeri 1 Seririt (2) To find out the students' responses to the application of e-learning systems with a blended learning model is used in Simulation and Digital Communication subjects. The e-learning system used in this study is adeles2tp with the content of SMK Negeri 1 Seririt.This type of research is a quasi-experimental (quasi-experimental) design with Post Test Only Control Group Design. The study population included all class X Accounting students of SMK Negeri 1 Seririt Academic Year 2018/2019. The sample used was class X AK 1 which was used as the experimental class and $X A K 2$ which was used as the control class, with a total of 70 people. The data collection method used is a multiple choice test method to regulate the cognitive domain then analyzed by including the normality test, homogeneity test, hypothesis testing and questionnaire method to see the student response.The benefits of the results of this study can improve the learning outcomes of students' knowledge of Digital Simulation and Communication subjects and student responses to e-learning learning media.

Keywords: e-learning, blended learning, adeles2tp, Post Test Only Control Group Design. 


\section{ISSN 2252-9063 \\ Kumpulan Artikel Mahasiswa Pendidikan Teknik Informatika \\ (KARMAPATI) \\ Volume 8 Nomor 2 Tahun 2019}

\section{PENDAHULUAN}

Belajar merupakan suatu proses perubahan dari dalam kepribadian manusia dan perubahan tersebut ditampakkan dalam bentuk peningkatan kualitas dan kuantitas tingkah laku seperti peningkatan kecakapan, pengetahuan, sikap, kebiasaan, pemahaman, keterampilan, daya pikir, dan lain-lain. Proses belajar memerlukan suatu media yang dinamakan media pembelajaran (Hakim, 2005) [1].

Dalam proses belajar mengajar media pembelajaran merupakan suatu hal yang sangat penting dalam proses penyampaian materi pembelajaran ke peserta didik, disamping itu seorang guru harus memiliki strategi, model, metode, dan tujuan pembelajaran yang tepat diterapkan sesuai dengan karakteristik siswa guna meningkatkan hasil belajar siswa dalam proses pembelajaran. Media pembelajaran yang tepat dalam penggunaannya dapat membantu dan memperjelas materi pembelajaran yang dibahas oleh pendidik kepada peserta didik [2].

Berdasarkan hasil wawancara (terlampir) dengan guru pengampu mata pelajaran Simulasi dan Komunikasi digital yang dilaksanakan pada tanggal 26 Januari 2019 bahwa, kendala yang sering terjadi dalam pembelajaran Simulasi dan Komunikasi Digital yaitu siswa tidak tertarik dengan media pembelajaran yang sudah diterapkan sehingga siswa cenderung tidak fokus dan merasa bosan terhadap pelajaran dikelas, dan guru menginginkan penggunaan media pembelajaran yang lebih bervariasi dan memudahkan siswa dalam menerima pelajaran[3].

Dari permasalahan tersebut sudah saatnya metode pembelajaran yang diterapkan dalam kegiatan belajar mengajar memanfaatkan perkembangan teknologi yang mengandung prinsip keterkinian. Dalam prinsip keterkinian baik guru maupun siswa cenderung memanfaatkan metode pembelajaran yang modern seperti teknologi informasi dan komunikasi (TIK), bahan ajar, media pembelajaran dan lainlain. Menurut Sharon E. Smaldino dalam bukunya Instructional Technology \& Media for Learning (2012), teknologi memiliki peran penting dalam pendidikan siswa yang memiliki kekhususan. Teknologi dan media yang disesuaikan dan dirancang khusus bisa memberi kontribusi bagi pengajaran yang efektif dari seluruh siswa dan bisa membantu mereka meraih potensi tertinggi mereka, terlepas dari kemampuan bawaan mereka itu [4].

Batasan masalah yang terdapat dalam penelitian yang akan dilakukan sebagai berikut:

1. Materi yang akan disajikan pada penelitian ini yaitu mengenai Simulasi dan Komunikasi Digital.

2. Penelitian ini menggunakan model pembelajaran Blended Learning berbantuan E-learning Adeles2tp pada mata pelajaran Simulasi dan Komunikasi Digital dan penilaian hasil belajar siswa hanya pada ranah kognitif.

\section{KAJIAN TEORI}

\section{A. Media Pembelajaran}

Media merupakan segala sesuatu yang dapat digunakan untuk menyampaikan pesan dari pengirim pesan kepada penerima pesan sehingga dapat merangsang pikiran, perasaan dan perhatian peserta didik untuk tercapainya tujuan pendidikan. Dalam proses pembelajaran terdapat proses komunikasi yang berlangsung dalam suatu sistem, dan di dalamnya terdapat media pembelajaran sebagai salah satu komponen sistem pembelajaran tersebut. Media Pembelajaran adalah segala sesuatu yang digunakan untuk menyalurkan informasi dari pengirim pesan (guru) ke penerima pesan (siswa), sehingga merangsang siswa untuk berpikir dan memperhatikan proses pembelajaran agar proses belajar dapat terjadi (Sugihartini, 2016).

Secara umum, manfaat media dalam proses pembelajaran adalah memperlancar interaksi antara guru dan siswa sehingga kegiatan pembelajaran akan lebih efektif dan efisien. Tetapi secara khusus ada beberapa manfaat media yang lebih rinci. Kemp dan Dayton (dalam Depdiknas, 2003) mengidentifikasikan beberapa manfaat media dalam pembelajaran yaitu:

1. Penyampaian materi pelajaran dapat diseragamkan.

2. Proses pembelajaran menjadi lebih jelas dan menarik

3. Proses pembelajaran menjadi lebih interaktif

4. Efisiensi dalam waktu dan tenaga

5. Meningkatkan kualitas hasil belajar siswa

6. Media memungkinkan proses belajar dapat dilakukan di mana saja dan kapan saja

7. Media dapat menumbuhkan sikap positif siswa terhadap materi dan proses belajar

8. Mengubah peran guru ke arah yang lebih positif dan produktif.

B. Model Pembelajaran Blended Learning

Model pembelajaran adalah suatu rencana atau pola yang dapat digunakan untuk membentuk kurikulum (rencana pembelajaran jangka panjang), merancang bahan-bahan pembelajaran, dan membimbing pembelajaran di kelas atau yang lain (Rusman, 2010).

Blended learning ini pada dasarnya merupakan gabungan keunggulan pembelajaran yang dilakukan secara tatap-muka dan secara virtual. Purtadi menjelaskan bahwa Blended learning adalah kombinasi berbagai media pembelajaran yang berbeda (teknologi, aktivitas, dan berbagai jenis peristiwa) untuk menciptakan program pembelajaran yang optimum untuk audiens (peserta didik) yang spesifik. 


\section{ISSN 2252-9063 \\ Kumpulan Artikel Mahasiswa Pendidikan Teknik Informatika \\ (KARMAPATI) \\ Volume 8 Nomor 2 Tahun 2019}

\section{KaRmapaTI}

C. Project Based Learning

Pembelajaran Berbasis Proyek (Project Based Learning) adalah model pembelajaran yang menggunakan proyek/kegiatan sebagai inti pembelajaran. Peserta didik melakukan eksplorasi, penilaian, interpretasi, sintesis, dan informasi untuk menghasilkan berbagai bentuk hasil belajar. Peran guru dalam Pembelajaran Berbasis Proyek sebaiknya sebagai fasilitator, pelatih, penasehat dan perantara untuk mendapatkan hasil yang optimal sesuai dengan daya imajinasi, kreasi dan inovasi dari siswa.

Pembelajaran Berbasis Proyek memiliki karakteristik sebagai berikut : 1) peserta didik membuat keputusan tentang sebuah kerangka kerja, 2) adanya permasalahan atau tantangan yang diajukan kepada peserta didik, 3) peserta didik mendesain proses untuk menentukan solusi atas permasalahan atau tantangan yang diajukan,4) peserta didik secara kolaboratif bertanggungjawab untuk mengakses dan mengelola informasi untuk memecahkan permasalahan, 5) proses evaluasi dijalankan secara kontinyu, 6) peserta didik secara berkala melakukan refleksi atas aktivitas yang sudah dijalankan, 7) produk akhir aktivitas belajar akan dievaluasi secara kualitatif dan, 8) situasi pembelajaran sangat toleran terhadap kesalahan dan perubahan.

\section{E-learning Adeles2tp}

E-learning singkatan dari Elektronic Learning, adalah media pembelajaran berbasis internet untuk membantu interaksi guru dengan siswa dalam proses belajar mengajar. Eleaning adalah sebuah konsep belajar yang berasal dari penggunaan teknologi informasi dan komunikasi (TIK) untuk memberikan pengajaran dan pembelajaran (Sindu, 2013). Dengan semakin banyaknya penggunaan e-learning sebagai standar pembelajaran alternative, sehingga memicu banyak pembuatan aplikasi yang mendukung proses pembelajaran elearning yang berbasis web. Aplikasi ini dikenal dengan nama Learning Management System (LMS).

Adeles $2 t p$ merupakan sistem adaptive learning yang mampu untuk mengakomodasi permasalahan perbedaan karakteristik peserta didik, berbeda dengan e-learning pada umumnya yang mengganggap pengguna e-learning semua sama atau homogeny. Dengan menggunakan Adeles2tp pengajar dapat memberikan materi pembelajaran yang sesuai dengan kemampuan pengguna, dan cara mempresentasikan materi pembelajarannya sesuai dengan gaya belajar pengguna. Gaya belajar adalah cara seseorang menyerap informasi melalui indera yang mereka miliki. Masing-masing orang mempunyai kecenderungan berbeda-beda dalam menyerap informasi. Hal ini menyebabkan apa yang dipelajari tidak sesuai dengan karakteristik dari masing-masing peserta didik, sehingga apa yang diperoleh juga menjadi kurang optimal.
Adapun fitur-fitur yang terdapat pada e-learning Adeles2tp dengan content Simulasi dan Komunikasi Digital adalah sebagai berikut:

\section{Halaman Awal E-learning}

Pada halaman ini merupakan tampilan awal dari $e$ learning yang akan digunakan oleh siswa. Tampilan awal dari e-learning ini berisikan plugin login, petunjuk registrasi pada e-learning, course sekolah, penggunaan Bahasa pada $e$ learning dan lain-lain.

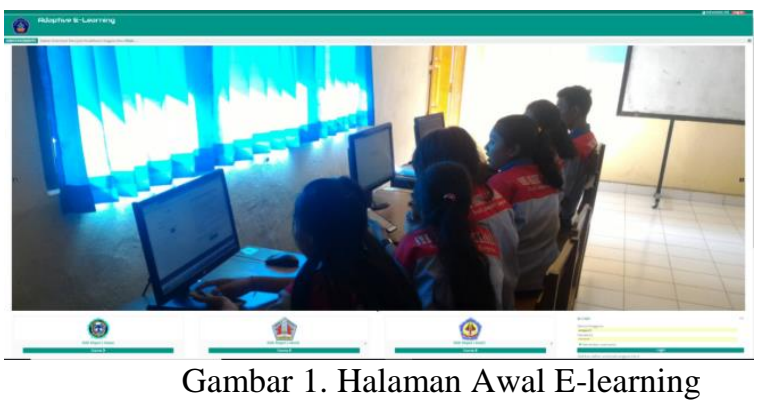

\section{Halaman Login}

Pada halaman ini, untuk dapat bisa masuk ke content, guru dan siswa harus melakukan login terlebih dahulu dengan memasukkan username dan password. Jika belum memiliki username dan password, pengguna dapat melakukan pembuatan akun terlebih dahulu agar bisa login. Tampilan antarmuka halaman login untuk guru dan siswa memiliki tampilan yang sama.

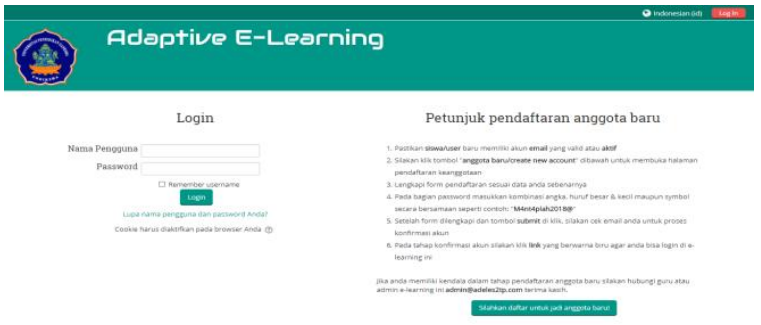

Gambar 2. Halaman Login

\section{Halaman Registrasi Anggota Baru}

Halaman ini digunakan pengguna untuk membuat akun baru. Hasil pengembangan halaman daftar anggota baru (guru) dan halaman daftar anggota baru (siswa). 


\section{Kumpulan Artikel Mahasiswa Pendidikan Teknik Informatika}

(KARMAPATI)

Volume 8 Nomor 2 Tahun 2019

\section{KดRMAPคTI}

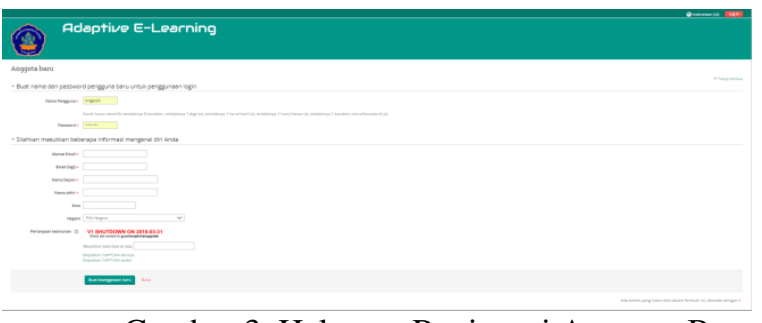

Gambar 3. Halaman Registrasi Anggota Baru

\section{Halaman Utama Pengguna}

Halaman ini merupakan tampilan awal ketika pengguna berhasil melakukan login. Halaman ini berisi informasi tentang materi, pre-tes, tugas, post-test dari setiap kegiatan pembelajaran.

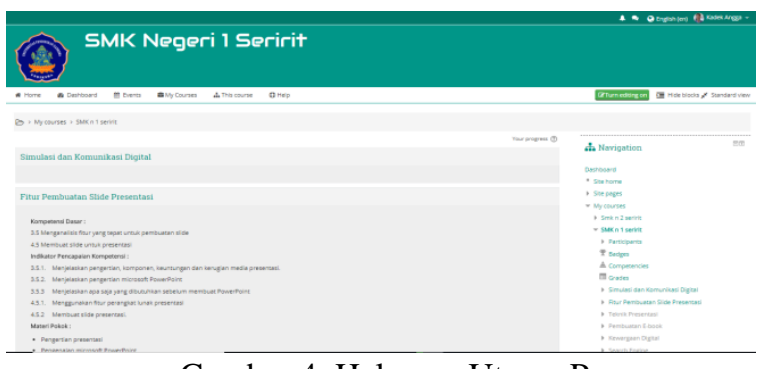

Gambar 4. Halaman Utama Pengguna

\section{Halaman Nilai}

Halaman nilai merupakan halaman yang menampilkan nilai-nilai yang diperoleh siswa dengan dibuatkan grafik.

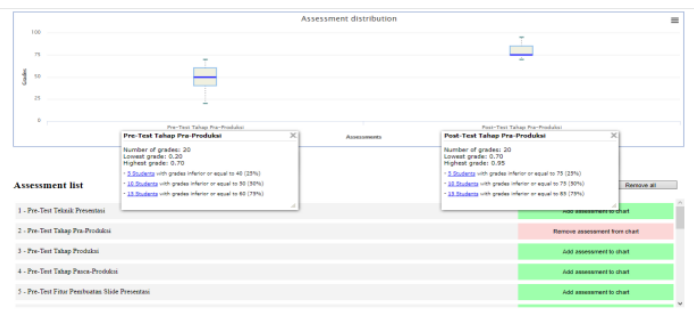

Gambar 5. Halaman Nilai

\section{Halaman Forum}

Halaman forum merupakan halaman yang digunakan untuk melakukan diskusi dengan guru dan siswa terkait dengan masalah - masalah yang dihadapi saat pembelajaran online.

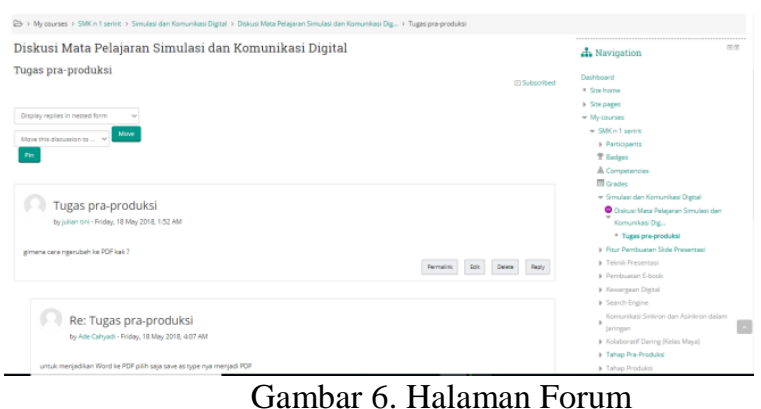

7. Halaman Aktifitas Siswa

Halaman Aktivitas Siswa merupakan halaman aktivitas yang diakses oleh siswa. Halaman ini akan menampilkan nama siswa yang mengakses aktivitas yang terdapat pada $e$ learning.

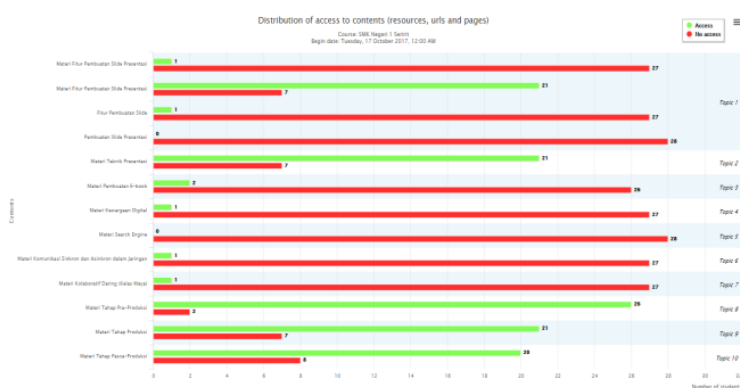

Gambar 7. Halaman Aktifitas Siswa

\section{Halaman Perkembangan Siswa}

Halaman perkembangan siswa merupakan halaman yang menampilkan aktivitas-aktivitas yang belum dilakukan dan sudah dilakukan siswa, untuk mengetahui sejauh mana perkembangan siswa tersebut dalam proses pembelajaran.

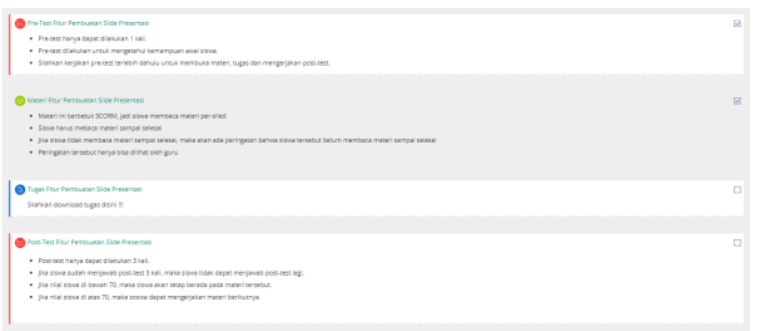

Gambar 8. Halaman Perkembangan Siswa

E. Modality Visual

Bobbi De Poter \& Mike Hernacki (dalam Sukadi, 2008), berdasarkan arti katanya, Gaya belajar visual adalah gaya 


\section{ISSN 2252-9063 \\ Kumpulan Artikel Mahasiswa Pendidikan Teknik Informatika \\ (KARMAPATI) \\ Volume 8 Nomor 2 Tahun 2019}

belajar dengan cara melihat, mengamati, memandang, dan sejenisnya. Kekuatan gaya belajar ini terletak pada indera penglihatan. Bagi orang yang memiliki gaya ini, mata adalah alat yang paling peka Menurut (Nini Subini, 2012) Gaya belajar secara visual dapat dilakukan seseorang untuk memperolah informasi seperti melihat gambar, diagram, peta, poster, grafik, dan sebagainya. Bisa juga dengan melihat data teks seperti tulisan dan huruf.

Karakteristik gaya belajar visual ini berhubungan dengan visualitas. Seorang peserta didik akan lebih mudah mengingat jika dibantu dengan gambar dan video, serta lebih suka membaca sendiri dari pada dibacakan oleh orang lain. Kelebihan dari gaya belajar visual antara lain: (1) mudah mengingat informasi yang di lihat, (2) memiliki minat yang kuat terhadap warna dan gambar, (3) cenderung lebih teliti karena sangat memperhatikan detail, (4) peserta didik tidak cepat bosan.

\section{F. Hasil Belajar}

Hasil belajar adalah kemampuan yang dimiliki siswa setelah ia menerima pengalaman belajar. Hasil belajar siswa pada hakikatnya adalah perubahan mencakup bidang kognitif, afektif dan psikomotoris berorientasi pada proses belajar mengajar yang dialami siswa (Sudjana, 2005).

\section{G. Hipotesis Penelitian}

Berdasarkan uraian dalam kerangka teoretik tersebut, hipotesis penelitian yang diajukan adalah sebagai berikut:

1. Terdapat hasil belajar yang lebih tinggi antara siswa yang menggunakan media E-learning bermodelkan Blended Learning dan siswa yang belajar tanpa menggunakan media $E$ learning bermodelkan Project Based Learning pada mata pelajaran Simulasi dan Komunikasi Digital di Kelas X Akuntansi SMK Negeri 1 Seririt.

2. Terdapat respon yang positif dari siswa kelas $\mathrm{X}$ Akuntansi SMK Negeri 1 Seririt dalam proses pembelajaran setelah menggunakan media E-learning Adeles2tp bermodelkan Blended Learning.

\section{METODE PENELITIAN}

\section{A. Rancangan Penelitian}

Penelitian ini bertujuan untuk mengetahui pengaruh $E$ learning Adeles2tp dengan konten Simulasi dan Komunikasi Digital bermodelkan Blended Learning terhadap hasil belajar. Jenis penelitian yang digunakan untuk mencapai tujuan tersebut adalah eksperimen semu (quasi experiment). Rancangan eksperimen yang digunakan adalah Posttest-Only Control Design. Kelompok yang diberi perlakuan disebut kelompok eksperimen dan kelompok yang tidak diberi perlakuan disebut kelompok control.

Tabel 1. Non-Equivalent Post-test Only Control Group Design

\begin{tabular}{|ccc|}
\hline Kelompok Eksperimen & $\mathrm{X}$ & $\mathrm{O}_{1}$ \\
\hline Kelompok Kontrol & - & $\mathrm{O}_{2}$ \\
\hline
\end{tabular}

Berdasarkan gambar diatas, $\mathrm{O}_{1}$ adalah post-test pada kelompok eksperimen, $\mathrm{O}_{2}$ adalah post-test pada kelompok kontrol, X adalah perlakuan E-learning Adeles2tp dengan konten Simulasi dan Komunikasi Digital bermodelkan Blended Learning.

B. Populasi dan Sampel Penelitian

Populasi penelitian ini adalah seluruh siswa kelas $\mathrm{X}$ Akuntansi SMK Negeri 1 Seririt pada semester genap tahun ajaran 2017/2018 berjumlah 101 orang.

Setelah Populasi ditentukan maka selanjutnya adalah menetukan sampel yang akan digunakan untuk meneliti. Secara umum, ada dua teknis pengambilan sampling yaitu sampel acak atau random sampling/ non probability sampling. Sebelum melanjutkan ke teknik random sampling terlebih dahulu dilakukan uji kesetaraan. Uji kesetaraan dilakukan untuk mengetahui setara atau tidaknya antar kelas dalam populasi. Pengukuran dilakukan dengan menganalisis total nilai siswa pada semester 1 tahun pelajaran 2018/2019. Untuk menentukan kelas yang akan digunakan setara, maka dapat dilakukan pengujian dengan menggunakan uji-t, berdasarkan hasil uji kesetaraan, kelas-kelas yang diasumsikan setara dapat digunakan sebagai sampel penelitian. Selanjutnya yang dilakukan dalam teknik random sampling yaitu melakukan pengundian untuk mendapatkan kelas eksperimen dan kelas kontrol. Berdasarkan hasil pengundian maka ditetapkan kelas $\mathrm{X}$ Akuntansu 1 sebagai kelompok eksperimen dan kelas $\mathrm{X}$ Akuntansi 2 sebagai kelompok kontrol.

\section{Metode Pengumpulan Data}

1. Metode Tes

Tujuan penelitian ini adalah ingin mengetahui hasil belajar kelas X Akuntansi pada mata pelajaran Simulasi dan Komunikasi Digital. Pengumpulan data dalam penelitian ini menggunakan metode tes. Tes hasil belajar yang dikembangkan disesuaikan dengan jenjang kemampuan kognitif. Dalam penelitian ini akan dilakukan test pada kelas eksperimen dan kelas kontrol yang disebut dengan post-test. Post-test dilakukan setelah kelas mendapat perlakuan yang berbeda, yaitu kelas eksperimen pembelajaran dengan 


\section{ISSN 2252-9063 \\ Kumpulan Artikel Mahasiswa Pendidikan Teknik Informatika \\ (KARMAPATI) \\ Volume 8 Nomor 2 Tahun 2019}

menggunakan media e-learning Adeles2tp dengan model pembelajaran blended Learning sebagai bahan ajar sedangkan kelas control menggunakan bahan ajar yang disediakan oleh guru di sekolah.

\section{Metode Angket}

Dalam penelitian ini angket yang digunakan yaitu angket respon siswa. Untuk memperoleh data mengenai respon siswa dengan diterapkannya media pembelajaran e-learning dengan model pembelajaran blended learning dalam pembelajaran Simulasi dan Komunikasi Digital dilakukan dengan menggunakan angket respon siswa dan disebarkan kepada siswa di akhir pembelajaran. Pemberian angket ini ditunjukkan untuk mengetahui seberapa positif respon siswa terhadap penerapan media pembelajaran e-learning adeles $2 t p$ dengan model pembelajaran blended learning dalam pembelajaran Simulasi dan Komunikasi Digital di kelas setelah di berikan perlakuan.

Angket respon siswa yang digunakan terdiri dari 10 item dengan pemberian skor minimal 1 dan skor maksimal 5 untuk setiap item angket. Jadi dalam implementasinya siswa memperoleh skor tanggapan dengan rentangan skor tertinggi 50 skor dan terendah 10 .

\section{Uji Coba Instrumen Penelitian}

Sebelum perangkat pembelajaran dan instrument penelitian digunakan maka terlebih dahulu dilakukannya pengujian untuk mendapat gambaran secara empiric apakah perangkat dan instrument layak digunakan dalam penelitian. Instrumen dikatakan sesuai jika instrumen tersebut sudah memenuhi kriteria Validitas, Reliabilitas. Kualitas item, khususnya di representasi oleh Indeks Kesukaran Butir (IKB), Indeks Daya beda Butir (IDB). Untuk memperoleh tujuan dari proses analisis, data terlebih dahulu dianalisis dengan menggunakan uji validitas tes dan reliabilitas tes.

\section{E. Teknik Analisi Data}

Teknik analisis data dalam penelitian ini menggunakan analisis statistik deskriptif dan statistik inferensial (uji-t) untuk menguji hipotesis penelitian. Data yang diperoleh dalam penelitian ini adalah data kuantitatif dan kualitatif. Data tersebut diolah menggunakan analisis statistik dan analisis non statistik. Data kuantitatif akan dianalisis dengan analisis statistic deskriptif untuk mendeskripsikan data hasil belajar siswa.

\section{F. Teknik Analisis Respon Siswa}

Respon siswa terhadap penggunaan media pembelajaran e-learning bermodelkan blended learning pada mata pelajaran simulasi dan komunikasi digital. Data yang dikumpulkan dengan menggunakan angket tanggapan siswa. Angket yang digunakan adalah skala Likert dengan pilihan Sangat Setuju
(SS), Setuju (S), Kurang Setuju (KS), Tidak Setuju (TS), dan Sangat Tidak Setuju (STS), sedangkan untuk respon negatif pemberian skor terbalik dengan item positif .

\section{HASIL DAN PEMBAHASAN}

A. Hasil Penelitian

Berdasarkan data pengukuran hasil belajar kognitif terhadap 35 siswa kelompok eksperimen, diperoleh data distribusi frekuensi skor post-test hasil belajar kognitif kelompok eksperimen, diketahui bahwa skor tertinggi siswa adalah 20 dan skor terendah siswa adalah 10 dengan rentangan 11, banyak kelas interval 6 dan panjang kelas interval adalah 2 .

Rata-rata skor hasil belajar dengan menggunakan $E$ learning Adeles2tp bermodelkan Blended Learning adalah 14,97 Berada pada interval $14,95<\mathrm{X} \leq 19,9$. Berdasarkan tabel di atas, dapat disimpulkan bahwa data hasil belajar siswa yang menggunakan E-learning Adeles2tp bermodelkan Blended Learning termasuk pada kategori 'Sangat Tinggi'.

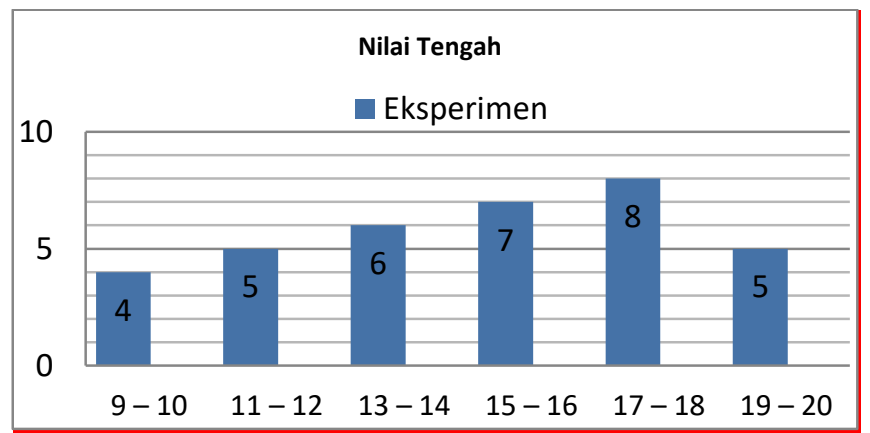

Gambar 9. Histogram Hasil Belajar Siswa Kelas Eksperimen

Berdasarkan data pengukuran hasil belajar kognitif terhadap 35 siswa kelompok kontrol, diperoleh data distribusi frekuensi skor post-test hasil belajar kognitif kelompok kontrol, diketahui bahwa skor tertinggi siswa adalah 18 dan skor terendah siswa adalah 8 dengan rentangan 11 , banyak kelas interval 6 dan panjang kelas interval adalah 2 .

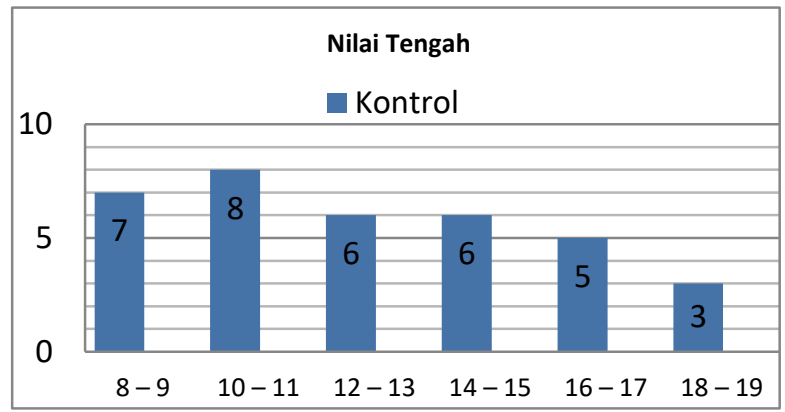

Gambar 10. Histogram Hasil Belajar Siswa Kelas Kontrol 
Rata-rata skor hasil belajar siswa yang belajar tanpa menggunakan media E-learning Adeles2tp bermodelkan Blended Learning adalah 12,63. Berada pada interval 11,65 $\leq \mathrm{X} \leq 14,95$. Berdasarkan tabel di atas, dapat disimpulkan bahwa data hasil belajar siswa yang belajar tanpa menggunakan media E-learning Adeles2tp bermodelkan Blended Learning pada kategori 'Tinggi'".

Uji prasyarat analisis dilakukan sebelum uji hipotesis. Terdapat beberapa persyaratan analisis yang harus dipenuhi, meliputi:

1. Uji Normalitas Sebaran Data

Berdasarkan hasil perhitungan post test kelompok eksperimen dan control dengan menggunakan SPSS 17.0, dari output analisis menunjukkan nilai kolmogrov Smirnov (a) adalah 0,200 dan 0,200 . Oleh karena itu nilai probabilitas kedua nilai signifikan $>0,05$, maka data hasil post-test kelompok eksperimen dan kontrol berdistribusi normal.

Tabel 2. Hasil uji normalitas Sebaran data dengan teknik Kolmogrov-Smirnov dengan Taraf Signifikansi 5\%.

\begin{tabular}{|c|r|r|r|r|r|r|}
\hline & \multicolumn{3}{|c|}{ Kolmogorov-Smimov $^{\mathrm{a}}$} & \multicolumn{3}{c|}{ Shapiro-Wilk } \\
\cline { 2 - 7 } Kelompok & Statistic & \multicolumn{1}{c|}{ Df } & \multicolumn{1}{c|}{ Sig. } & Statistic & df & \multicolumn{1}{c|}{ Sig. } \\
\hline Hasil Belajar eksperiemen & .108 & 35 & $.200^{\mathrm{z}}$ & .951 & 35 & .125 \\
Kontrol & .122 & 35 & $.200^{\mathrm{z}}$ & .937 & 35 & .045 \\
\hline
\end{tabular}

\section{Uji Homogenitas Varians}

Uji Homogenitas dimaksud untuk memperlihatkan bahwa dua atau lebih kelompok data sampel berasal dari populasi yang memiliki varians sama atau homogenitas. Pengujian ini dilakukan dengan menggunakan uji kesamaan varian melalui uji Test of Homogeneity of Variance untuk uji homogenitas secara terpisah.

Uji homogenitas varians menggunakan bantuan program SPSS-17.0 for windows pada taraf signifikan 0,05. Uji homogenitas dengan menggunakan Test of Homogeneity of Variance menghasilkan angka signifikan sebesar 0,971 untuk variabel hasil belajar. Hasil dapat ditampilkan pada Tabel sebagai berikut.

Tabel 3. Hasil analisis uji test of homogeneity of variance

\begin{tabular}{|c|r|r|r|r|}
\hline & $\begin{array}{c}\text { Levene } \\
\text { Statistic }\end{array}$ & \multicolumn{1}{c|}{ df1 } & \multicolumn{1}{c|}{ df2 } & \multicolumn{1}{c|}{ Sig. } \\
\hline Hasil Belajar Based on Mean & .001 & 1 & 68 & .971 \\
Based on Median & .005 & 1 & 68 & .946 \\
Based on Median and & .005 & 1 & 67.990 & .946 \\
with adjusted df & & & & \\
Based on trimmed mean & .001 & 1 & 68 & .975 \\
\hline
\end{tabular}

Hasil analisis menunjukan bahwa angka signifikan yang dihasilkan secara terpisah lebih besar dari 0,05. Dengan demikian dapat disimpulkan bahwa variabel hasil belajar adalah homogen, sehingga uji hipotesis menggunakan analisis Uji-t. Oleh karena sudah dipenuhi semua uji prasyarat analisis yaitu uji normalitas sebaran data dan uji homognitas varians sehingga uji hipotesis menggunakan Uji-t.

Pengujian hipotesis menyatakan terdapat perbedaan hasil belajar antara siswa yang belajar menggunakan E-learning Adeles2tp bermodelkan Blended Learning dengan siswa yang belajar tanpa menggunakan E-learning Adeles2tp bermodelkan Blended Learning, secara statistik dapat dirumuskan:

$\mathrm{H}_{0}:\left[\mu_{1} Y_{1}\right]=\left[\mu_{2} Y_{1}\right]$

$\mathrm{H}_{1}:\left[\mu_{1} Y_{1}\right] \neq\left[\mu_{2} Y_{1}\right]$

Keterangan :

$\mu_{1} Y_{1}$ : skor hasil belajar antara siswa yang belajar menggunakan E-learning Adeles2tp bermodelkan Blended Learning.

$\mu_{2} Y_{1}$ : skor hasil belajar siswa yang belajar tanpa menggunakan E-learning Adeles2tp bermodelkan Blended Learning

Hasil perhitungan analisis Uji-t dengan menggunkan Independent Samples Test berbantuan SPSS-17.0 for windows dapat dilihat pada Tabel sebagai berikut.

Tabel 4. Hasil uji hipotesis hasil belajar

\begin{tabular}{|c|c|c|c|c|c|c|c|c|c|c|}
\hline & \multicolumn{2}{|c|}{$\begin{array}{c}\text { Levene's Test for } \\
\text { Equality of } \\
\text { Variances }\end{array}$} & \multicolumn{7}{|c|}{ t-test for Equality of Means } \\
\hline & & \multirow[b]{2}{*}{ F } & \multirow[b]{2}{*}{ Sig. } & \multirow[b]{2}{*}{$\mathrm{t}$} & \multirow[b]{2}{*}{$\mathrm{df}$} & \multirow[b]{2}{*}{$\begin{array}{l}\text { Sig. (2- } \\
\text { tailed) }\end{array}$} & \multirow[b]{2}{*}{$\begin{array}{l}\text { Mean } \\
\text { Differen } \\
\text { ce }\end{array}$} & \multirow[b]{2}{*}{\begin{tabular}{|c|} 
Std. \\
Error \\
Differen \\
ce \\
\end{tabular}} & \multicolumn{2}{|c|}{$\begin{array}{l}95 \% \text { Confidence } \\
\text { Interval of the } \\
\text { Difference }\end{array}$} \\
\hline & & & & & & & & & Lower & Upper \\
\hline \multirow[t]{2}{*}{\begin{tabular}{|l} 
Hasil \\
Belajar
\end{tabular}} & $\begin{array}{l}\text { Equal } \\
\text { variances } \\
\text { assumed }\end{array}$ & .001 & .971 & 3.001 & 68 & .000 & 2.343 & .781 & .785 & 3.901 \\
\hline & $\begin{array}{l}\text { Equal } \\
\text { variances not } \\
\text { assumed }\end{array}$ & & & 3.001 & $\begin{array}{r}67.96 \\
4\end{array}$ & .000 & 2.343 & .781 & .785 & 3.901 \\
\hline
\end{tabular}




\section{ISSN 2252-9063 \\ Kumpulan Artikel Mahasiswa Pendidikan Teknik Informatika \\ (KARMAPATI) \\ Volume 8 Nomor 2 Tahun 2019}

Berdasarkan Tabel di atas, dapat dilihat bahwa besar signifikan (2-tailed) sebesar 0,000. Hasil ini menunjukan besar signifikan lebih kecil dari $0,05(\mathrm{p}<0,05)$, sehingga hasilnya adalah signifikan (ada perbedaan yang signifikan). Hal ini berarti hipotesis nol $\left(\mathrm{H}_{0}\right)$ ditolak dan hipotesis alternatif $\left(\mathrm{H}_{1}\right)$ diterima. Yang menyatakan bahwa terdapat perbedaan secara signifikan antara siswa yang belajar menggunakan E-learning Adeles2tp bermodelkan Blended Learning dengan siswa yang belajar tanpa menggunakan E-learning Adeles2tp bermodelkan Blended Learning pada kelas X Akuntansi di SMK N 1 Seririt.

Dari penyebaran angket respon yang disebarkan kepada siswa pada akhir penelitian untuk mengetahui tanggapan atau respon siswa terhadap penggunaan E-learning Adeles2tp bermodelkan Blended Learning pada mata pelajaran simulasi dan komunikasi digital. Dari hasil tersebut diperoleh data mengenai jumlah skor respon siswa sebesar 1243 Skor rata rata respon siswa yang dianalisis dengan rumus :

$$
\begin{aligned}
\overline{\mathrm{X}}=\frac{\sum \mathrm{X}}{\mathrm{N}} & =\frac{\mathbf{1 2 4 3}}{\mathbf{3 5}} \\
& =35,51
\end{aligned}
$$

Data respon siswa terhadap penggunaan E-learning Adeles2tp bermodelkan Blended Learning pada mata pelajaran simulasi dan komunikasi digital dapat disajikan di histogram dibawah

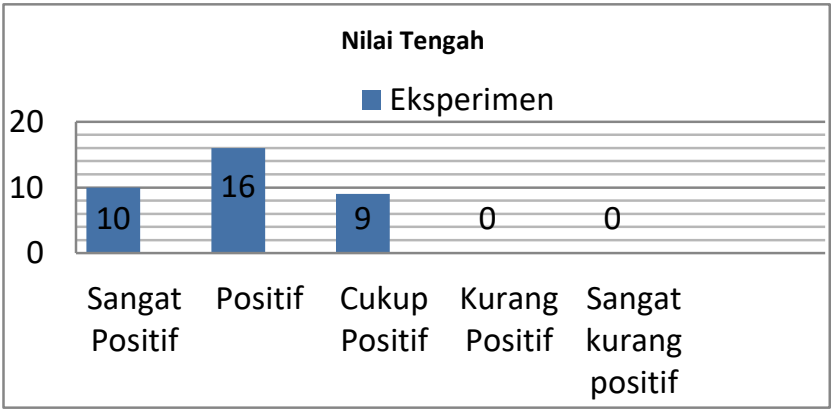

Gambar 11. Histogram Data Respon Siswa

Berdasarkan gambar diatas dapat diketahui bahwa respon siswa terhadap penggunaan E-learning Adeles2tp bermodelkan Blended Learning terhadap mata pelajaran simulasi dan komunikasi digital sebanyak $28,57 \%$ berkategori sangat positif, sebanyak $45,71 \%$ berkategori positif, $25,71 \%$ berkategori cukup positif serta tidak ada respon penggunaan E-learning Adeles2tp bermodelkan Blended Learning yang berkategori kurang positif dan sangat kurang positif.

\section{B. Pembahasan Hasil Penelitian}

Pada bagian ini dibahasa lebih lanjut mengenai hasil penelitian yang telah diperoleh. Hasil penelitian meliputi analisis deskriptif dan analisis statistik yang mengungkap pengaruh variable bebas terhadap variable terikat. Variabel bebas dalam penelitian ini adalah E-learning Adeles2tp bermodelkan Blended Learning sedangkan variable terikat dalam penelitian ini adalah hasil belajar Mata Pelajaran Simulasi dan Komunikasi Digital.

Penelitian ini dilaksanakan dalam 3 kali pertemuan, yang terdiri dari 2 kali proses pembelajaran dan 1 kali pertemuan untuk post test yang dilakukan pada kelas eksperimen dan kontrol.

Analisis dari hasil penelitian didapat bahwa rata-rata post test hasil belajar Simulasi dan Komunikasi Digital yang dicapai siswa pada kelompok eksperimen adalah 14,97 sedangkan rata-rata post test hasil belajar Simulasi dan Komunikasi Digital untuk kelompok kontrol sebesar 12,63. Dengan demikian, rata-rata post test hasil belajar Simulasi dan Komunikasi Digital pada kelompok eksperimen lebih besar dibandingkan kelompok kontrol. Untuk perhitungan normalitas, homogenitas, dan uji t menggunakan SPSS-17.0 for Windows hasilnya tidak jauh berbeda, dimana kedua kelompok baik kelompok eksperimen dan kelompok kontrol memiliki data yang normal dan homogeny.

Kedua temuan tersebut menunjukkan bahwa terdapat hasil belajar yang lebih tinggi pada pelajaran Simulasi dan Komunikasi Digital antara siswa yang belajar menggunakan sistem E-learning Adeles2tp bermodelkan Blended Learning dengan siswa yang belajar menggunakan media pembelajaran power point dengan model project based learning di SMK Negeri 1 Seririt.

Hasil belajar kelas eksperimen yang menggunakan sistem E-learning Adeles2tp bermodelkan Blended Learning pada Mata Pelajaran Simulasi dan Komunikasi Digital lebih baik, dilihat dari nilai rata-rata skor siswa kelompok eksperimen lebih tinggi dibandingkan kelompok kontrol $(14,97>12,63)$. Hal ini disebabkan karena dengan menggunakan sistem Adaptive Learning siswa dapat belajar sesuai dengan karakteristik masing-masing, sistem E-learning Adeles2tp menerapkan gaya belajar Modality Visual yang merupakan gaya belajar dengan cara melihat, mengamati, memandang, dan sejenisnya, sehingga siswa dapat memilih materi berupa 


\section{ISSN 2252-9063 \\ Kumpulan Artikel Mahasiswa Pendidikan Teknik Informatika \\ (KARMAPATI) \\ Volume 8 Nomor 2 Tahun 2019}

video, teks dan gambar yang sudah disediakan oleh pengajar di dalam e-learning. Sehingga dapat dikatakan bahwa penggunaan media pembelajaran E-learning Adeles2tp memiliki peranan penting dalam meningkatkan hasil belajar siswa.

Hasil analisis respon siswa terhadap pengunaan $E$ learning Adeles2tp bermodelkan Blended Learning terhadap mata pelajaran simulasi dan komunikasi digital sebanyak $28,57 \%$ berkategori sangat positif, sebanyak $45,71 \%$ berkategori positif, $25,71 \%$ berkategori cukup positif serta tidak ada respon penggunaan E-learning Adeles2tp bermodelkan Blended Learning yang berkategori kurang positif dan sangat kurang positif, dengan persentase rata- rata respon siswa sebesar $35.51 \%$.

Dalam penelitian ini adapun kendala-kendala yang dihadapi peneliti saat menerapkan E-learning adalah ada beberapa siswa tidak memiki jaringan internet sehingga peneliti mengatasinya dengan menyediakan jaringan internet yang dapat digunakan dalam proses pembelajaran berlangsung.

Kedua, Guru memiliki kesibukan yang tidak dapat ditinggalkan sehingga tidak jarang pembelajaran dimulai lebih lambat dan proses belajar dipercepat dari pada waktu yang sudah ditentukan. Solusi yang diberikan terhadap kendala ini adalah, mahasiswa selaku peneliti mengarahkan siswa untuk tetap mempelajari materi yang sudah ada pada E-learning Adeles2tp sehinggga pelaksanaan pembelajaran dapat berlangsung dengan baik.

Berdasarkan pertimbangan-pertimbangan teoritik dan operasional, maka implikasi dari penelitian ini jika dilihat dari teori belajar konstruktivisme adalah proses belajar dan pembelajaran dikelas. Siswa harus dapat mengaplikasikan ideide mereka sendiri, siswa harus mengkonstruksikan pengetahuan mereka sendiri sehingga hasil belajar dicapai dengan lebih baik. Berdasarkan hal itu media ajar yang dapat digunakan untuk mencapai hasil belajar dengan lebih baik adalah media pembelajaran E-learning Adeles2tp pada mata pelajaran simulasi dan komunikasi digital.

\section{PENUTUP}

\section{A. Simpulan dan Saran}

Berdasarkan hasil penelitian dan pembahasan, dapat dikemukakan beberapa simpulan. Adapun simpulan yang akan dikemukakan dalam penelitian ini adalah sebagai berikut:

1. Terdapat hasil belajar yang lebih tinggi antara siswa yang belajar menggunakan media pembelajaran E-learning Adeles $2 t p$ bermodelkan Blended Learning dan siswa yang belajar menggunakan media power point pada mata pelajaran Simulasi dan Komunikasi Digital siswa kelas X Jurusan
Akuntansi SMK Negeri 1 Seririt. Dilihat rata-rata hasil belajar kelompok eksperimen dengan penggunaan E-learning Adeles2tp bermodelkan Blended Learning adalah 14,97 sedangkan rata-rata post test untuk kelompok kontrol sebesar 12,63. Berdasarkan rata-rata belajar tersebut maka dapat disimpulkan bahwa hasil belajar lebih tinggi terdapat pada siswa yang menggunakan media pembelajaran E-learning Adeles $2 t p$ bermodelkan Blended Learning.

2. Hasil dari analisis respon siswa dari penggunaan E-learning Adeles $2 t p$ bermodelkan Blended Learning pada mata pelajaran simulasi dan komunikasi digital dilihat dari rata-rata skor respon siswa sebesar 35,51 adalah termasuk dalam kategori positif.

Berdasarkan hasil penelitian dapat diajukan beberapa saran guna meningkatkan kualitas pembelajaran Simulasi dan Komunikasi Digital

1. Hasil penelitian ini menunjukkan bahwa siswa yang belajar dengan menggunakan E-learning Adeles2tp bermodelkan Blended Learning memperoleh hasil belajar yang lebih baik daripada siswa yang menggunakan media pembelajaran konvensional. Oleh karena itu, penulis menyarankan kepada guru pengajar untuk menerapkan media pembelajaran $E$ learning Adeles2tp bermodelkan Blended Learning pada proses pembelajaran selanjutnya.

2. Peneliti juga menyarankan kepada peneliti lain yang akan melakukan penelitian sejenis agar bisa mengkondisikan keadaan kelas sebaik mungkin ketika melaksanakan tes akhir (post test).

\section{REFERENSI}

[1] Agustini,K., Wahyuni,D.S.,(2013). Pengaruh Penggunaan Simulasi Binary Tree Berbasis CAI Terhadap Motivasi dan Hasil Belajar Matematika Diskrit Mahasiswa Jurusan PTI Undiksha. Jurnal Pendidikan Indonesia. ISSN: 2303-255x Hal: 162-172.

[2] Arikunto, S. (1993). Procedure penelitian Suatu Pendekatan Praktek. Jakarta: PT Rineka Cipta.

[3] Azwar,S.(2012). Reliabilitas dan Validitas. Yogyakarta: Pustaka Pelajar.

[4] Arikunto, S. (2005). Managemen Penelitian. Jakarta: PT. Rineka Cipta.

[5] Candiasa, I. M. (2010). Statistik Multivariat Disertai Aplikasi SPSS. Singaraja: Unit Penerbit Undiksha.

[6] Candiasa, I.M. (2011). Pengujian Instrumen Penelitian disertai Aplikasi ITEMAN dan BIGSTEPS. Singaraja: Unit Penerbitan Undiksha.

[7] Nursalam, \& Efendi, F. (2008). Pendidikan dan Keprawatan .Jakarta: Salemba Medika

[8] Prasojo, Lantip Diat dan Riyanto. 2011. Teknologi Informasi Pendidikan. Yogyakarta: Gava Media

[9] Putrayasa, I.B. (2013). Landasan Pembelajaran. Singaraja-Bali: Undiksha Press.

[10] Sanjaya, W.(2009). Penelitian Tindakan Kelas. Jakarta: Prenadamamedia Group. 